\title{
CONTRATOS BANCÁRIOS E RELAÇÃO DE \\ CONSUMO: \\ ANÁLISE PROPEDÊUTICA DA EFICÁCIA DOS \\ DIREITOS FUNDAMENTAIS NAS RELAÇÕES \\ ENTRE PARTICULARES
}

André Pires Gontijo*

\section{Introdução}

Nos dias atuais, em que a pós-modernidade permeia as relações jurídicas, propiciando a interdisciplinaridade e a flexibilidade da interpretação dos dispositivos postos, o sistema financeiro, como um dos pilares do Estado Constitucional brasileiro, passou e passa por transformações a cada momento.

Nesse sentido, em uma perspectiva real e concretista, e em uma vertente mais pragmática, as transformações científicas e tecnológicas aproximam o cidadão da informação, que se vê rodeado por diversos instrumentos hábeis a lhe proporcionar conforto, comodidade e impulsionar suas relações jurídicas, tanto no âmbito laboral e empresarial, como também no contexto das relações de consumo.

Assim sendo, os contratos bancários, que se tornam mais complexos e mais necessários à vida dos cidadãos, estão em debate nas instâncias de poder. A Emenda Constitucional n. 40, de 2003 (que alterou todo o sistema financeiro nacional, modificando o caput do art. 192 e revogando os demais dispositivos) teve como impulso criador os fatores reais de poder das instituições financeiras, as quais, de maneira legítima, atuaram perante o Poder Legislativo, a fim de aprovar a Proposta de Emenda Constitucional.

Nessa perspectiva, desde o ano de 2002 a Suprema Corte brasileira enfrenta a Ação Direta de Inconstitucionalidade (ADI) n. 2.591, no sentido de discutir se há incidência do Código de Defesa do Consumidor (CDC) nas relações envolvendo contratos bancários.

\footnotetext{
* Bacharel em Direito pelo UniCEUB, aluno do Programa de Mestrado em Direito das Relações Internacionais do UniCEUB, pesquisador do Núcleo de Estudos Constitucionais - NEC (UnB/UNICEUB) e do grupo de pesquisa Estudo da União Européia e Integração Regional (UnB/UniCEUB), aluno-pesquisador do $3^{\circ}$ PIC/UniCEUB/CNPq (2\%/2004-1\%/2005), Servidor Público do Superior Tribunal de Justiça, lotado no Gabinete da Ministra Maria Thereza de Assis Moura (STJ). E-mail: andre.gontijo@gmail.com
} 
Logo, o objetivo do presente trabalho é justamente envolver os intérpretes da Constituição $^{1}$ na discussão institucional, analisando os argumentos do Supremo Tribunal Federal (STF) e, de maneira propedêutica, iluminar o debate constitucional com a teoria da eficácia dos direitos fundamentais nas relações entre particulares.

Para tanto, utilizar-se-á como metodologia jurídica ${ }^{2}$ o tipo de pesquisa instrumental (com consulta à doutrina, à jurisprudência e à legislação referente ao tema) e as técnicas de pesquisa bibliográfica, documental e de observação, a fim de usar e discutir as idéias contidas em seminários realizados ${ }^{3}$, nos votos da ADI n. $2.591^{4}$, bem como o histórico jurisprudencial existente no STF em relação ao direito econômico na Constituição ${ }^{5}$.

Em relação ao referencial teórico, além das idéias contidas nas obras do professor

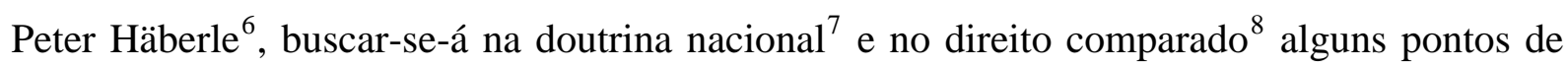

${ }^{1}$ Cf. HÄBERLE, Peter. Hermenêutica Constitucional. A sociedade aberta de intérpretes da Constituição: contribuição para a interpretação pluralista e "procedimental" da Constituição. Trad. Gilmar Ferreira Mendes. Porto Alegre: Sergio Antonio Fabris, 1997.

${ }^{2}$ Cf. SILVA, Christine Oliveira Peter da. A pesquisa científica na graduação em Direito. In: Universitas/ Jus: Brasília, n. 11, p. 25-43, dez. 2004; SILVA, Christine Oliveira Peter da. Discussões prático-metodológicas sobre relatórios de pesquisa no contexto da iniciação científica em Direito. In: Universitas/ Jus: Revista da Faculdade de Ciências Jurídicas e Ciências Sociais do Centro Universitário de Brasília - UniCEUB. Brasília, n. 12, p. 39-54, jul. 2005; VIEIRA, Liliane dos Santos. Pesquisa e monografia jurídica na era da informática. 2. ed. Brasília, Brasília Jurídica, 2005.

${ }^{3}$ Cf. MARQUES, Cláudia Lima. Constituição, Direito Privado e o Consumidor; e MENDES, Gilmar Ferreira. A Eficácia dos Direitos Fundamentais nas Relações Privadas. In: IV Seminário de direito privado - A constituição e a vida privada - Constituição e pessoa humana \& constituição e atividade econômica, 22 a 24 de junho de 2006. Brasília: Instituto Brasiliense de Direito Público, 2006.

${ }^{4}$ Cf. SUPREMO TRIBUNAL FEDERAL. Plenário. ADI n. 2.951-DF. Relator Ministro Carlos Velloso. Voto do Ministro Néri da Silveira. Informativo (STF) n. 264; Voto do Ministro Nelson Jobim. Últimas Notícias (STF); Voto do Ministro Eros Grau. Últimas Notícias (STF). Todos disponíveis em: <http://www.stf.gov.br>. Acesso em 01.06.2006.

${ }^{5}$ Cf. SUPREMO TRIBUNAL FEDERAL. Plenário. ADI n. 319-QO. Relator Ministro Moreira Alves, DJ 30.04.1993; MI n. 542. Relator Ministro Celso de Mello, DJ 28.06.2002; RE n. 387.404. Relator para acórdão Ministro Joaquim Barbosa, DJ 26.03.2004; 1. Turma. RE n. 286.963-MG. Relator Ministro Sepúlveda Pertence. Informativo (STF) n. 386. Disponíveis em: <http://www.stf.gov.br>. Acesso em 04.06.2006.

${ }^{6}$ Cf. HÄBERLE, Peter. Hermenêutica Constitucional. A sociedade aberta de intérpretes da Constituição: contribuição para a interpretação pluralista e "procedimental" da Constituição. Trad. Gilmar Ferreira Mendes. Porto Alegre: Sergio Antonio Fabris, 1997; HÄBERLE, Peter. La libertad fundamental en el Estado Constitucional. Trad. Jürgen Saligmann, César Landa, Carlos Ramos e Antonio Luya. San Miguel, Peru: Fondo Editorial de la Pontificia Universidad Católica del Peru, 1997; HÄBERLE, Peter. Libertad, Igualdad, Fraternidad: 1789 como historia, actualidad y futuro del Estado Constitucional. Trad. Ignacio Gutiérrez Gutiérrez. Madri: Minima Trotta, 1998.

${ }^{7}$ Cf. SARLET, Ingo Wolfgang. Direitos Fundamentais e Direito Privado: algumas considerações em torno da vinculação dos particulares aos direitos fundamentais. In: Revista de Direito do Consumidor, São Paulo: Revista dos Tribunais, n. 36, p. 54-103, out./dez. 2000; ÁVILA, Humberto Bergmann. Teoria dos princípios: da definição à aplicação dos princípios jurídicos. 3. ed., aumentada. São Paulo: Malheiros Editores, 2004.

${ }^{8}$ Cf. HESSE, Konrad. Derecho Constitucional y derecho privado. Madrid: Civitas, 1995; RODRIGUEZ RUIZ, Bianca. Resenha do livro de NARANJO DE LA CRUZ, Rafael. Los límites de los derechos y fundamentales en las relaciones entre particulares: la buena fe. Madrid: Centros de Estudios Políticos y Constitucionales, 2000. 
debate para a inserção da teoria da eficácia dos direitos fundamentais nas relações entre os particulares, como também no que diz respeito ao diálogo das fontes (público e privado) em razão da constitucionalização do direito $^{9}$, tudo isso reflexo do fenômeno da pósmodernidade ${ }^{10}$, norteador das pesquisas nesse começo do século XXI.

\section{Notícia Histórica Da ADI 2.591}

Em 17.04.2002, o Ministro Carlos Velloso (Relator) proferiu voto no sentido de empregar uma interpretação conforme a Constituição, a fim de excluir a taxa de juros reais nas operações bancárias ou a sua fixação em $12 \%$ ao ano da incidência do Código de Defesa do Consumidor (CDC) ${ }^{11}$.

O Ministro Néri da Silveira, por sua vez, julgou improcedente o pedido formulado na inicial, por considerar a proibição da aplicação do CDC relativamente às matérias previstas no art. 192 da Constituição, salientando que o eventual surgimento de questão relativa aos pressupostos do sistema financeiro deverá ser resolvida de maneira específica. ${ }^{12}$

O Ministro Nelson Jobim pediu vista dos autos. Retornando em 22.02.2006, proferiu voto no sentido de dar interpretação conforme a Constituição. O Ministro Eros Grau,

In: Teoría y realidad constitucional, n. 10-11, p. 792-798, 2003, p. 792. Disponível em: <http://www.juridicas.unam.mx/publica/librev/rev/trcons/cont/10/rec/rec35.pdf>. Acesso em: 25.10.2005.

${ }^{9}$ BARROSO, Luís Roberto. Neoconstitucionalismo e constitucionalização do Direito. O triunfo tardio do Direito Constitucional no Brasil. Jus Navigandi, Teresina, a. 9, n. 851, 01.11.2005. Disponível em: <http://jus2.uol.com.br/doutrina/texto.asp?id=7547>. Acesso em: 01.11.2005; MARQUES, Cláudia Lima. Contratos no Código de Defesa do Consumidor. 3. ed., rev., atual. e ampl. São Paulo: Revista dos Tribunais, 1999.

${ }^{10}$ Para explicar a influência do fenômeno da pós-modernidade, adota-se as palavras da professora Christine Peter: “A expressão pós-modernidade neste contexto quer significar aquilo que ainda está em construção, ou seja, o paradigma indefinido que se nos apresenta para conformação no último quarto do século XX e neste primeiro quarto do século XXI. Os autores resistem à expressão, com alguma razão, tendo em vista que não há univocidade em seu significado. Mas em um contexto de estabelecimento de novos pontos de vista, bem como de novas abordagens, que não se pretendem definitivas, mas destemidas (aberta a críticas) e comprometidas com a realidade circundante, reputo adequado e pertinente, até mesmo imprescindível, o emprego da expressão.” Cf. SILVA, Christine Oliveira Peter da. Interpretação constitucional no século XXI: o caminhar metodológico para o concretismo constitucional sob a influência de Peter Häberle. Direito Público. Porto Alegre: Síntese; Brasília: Instituto Brasiliense de Direito Público, a. 02., n. 08, p. 05-39, abr./jun. 2005.

${ }^{11}$ Este entendimento foi de encontro ao que disciplinava a Constituição Federal (CF), art. 192, § $3^{\circ}$ - As taxas de juros reais, nelas incluídas comissões e quaisquer outras remunerações direta ou indiretamente referidas à concessão de crédito, não poderão ser superiores a doze por cento ao ano; a cobrança acima deste limite será conceituada como crime de usura, punido, em todas as suas modalidades, nos termos que a lei determinar. (Este dispositivo - como toda a disciplina do Sistema Financeiro Nacional - foi reformulado pela EC n. 40, de 2003).

${ }^{12}$ Cf. SUPREMO TRIBUNAL FEDERAL. Plenário. ADI n. 2.951-DF. Relator Ministro Carlos Velloso. Voto do Ministro Néri da Silveira. Informativo (STF) n. 264. Disponível em: <http://www.stf.gov.br>. Acesso em 01.06.2006. 
a seu turno, também pediu vista, retornando com estes em 04.05.2006, julgando improcedente a ação, acompanhado pelos Ministros Joaquim Barbosa, Sepúlveda Pertence e Carlos Britto.

O desfecho final do julgamento ocorreu em 07.06.2006, com o score de 09 votos julgando a ação improcedente contra 02 votos que aplicavam a interpretação conforme a Constituição. Na ocasião do desfecho, salienta-se o voto do Ministro Celso de Mello, o qual ressaltou a qualificação da proteção do consumidor como valor constitucional (CF, art. 170, V), no sentido de que as atividades econômicas estão sujeitas à fiscalização e à ação normativa do Estado, como ente regulador (CF, art. 174, caput) da atividade econômica e defensor do consumidor (CF, art. $5^{\circ}$, XXXII), com o dever de evitar práticas abusivas por parte das instituições bancárias. ${ }^{13}$

Assim, passa-se agora à análise dos fundamentos acerca da aplicação do CDC nas relações bancárias.

\section{Os Fundamentos Favoráveis e Contrários à Aplicação Do CDC nas Relações Bancárias}

O Ministro Moreira Alves, em Questão de Ordem na ADI n. 319, ressalta a defesa do consumidor em relação ao abuso do poder econômico:

Em face da atual Constituição, para conciliar o fundamento da livre iniciativa e do princípio da livre concorrência com os da defesa do consumidor e da redução das desigualdades sociais, em conformidade com os ditames da justiça social, pode o Estado, por via legislativa, regular a política de preços de bens e de serviços, abusivo que é o poder econômico que visa ao aumento arbitrário dos lucros. ${ }^{14}$

É com esse espírito que se pretende analisar os fundamentos a favor e contra a aplicação do CDC às relações bancárias, em especial mediante a análise dos votos dos Ministros Nelson Jobim e Eros Grau acerca do julgamento da ADI n. 2.591-DF.

\subsection{O Voto do Ministro Nelson Jobim}

\footnotetext{
${ }^{13}$ Cf. DIRETO DO PLENÁRIO: Regras do Código de Defesa do Consumidor valem para os bancos. Últimas Notícias (STF), 07.06.2006. Disponível em: <http://www.stf.gov.br>. Acesso em: 07.06.2006.

${ }^{14}$ Cf. SUPREMO TRIBUNAL FEDERAL. Plenário. ADI n. 319-QO. Relator Ministro Moreira Alves, DJ 30.04.1993. Disponível em: <http://www.stf.gov.br>. Acesso em 01.06.2006.
} 
O Ministro Nelson Jobim assevera que existe uma diferença na composição e no funcionamento do sistema de proteção do consumidor e de proteção do poupador e do mutuário, de acordo com a lógica das premissas de proteção de cada um dos sistemas. ${ }^{15}$

O Ministro ressalta que as relações entre consumidor e fornecedor não estão em pé de igualdade, de tal sorte que é necessária a intervenção do Poder Público, a fim de que o fornecedor não utilize sua liberdade negocial de contratar para opor seu poderio econômico em face do consumidor. Dessa forma, a Constituição possui preocupação direta com a proteção do consumidor (CF, art. $5^{\circ}$, XXXII), procurando compensar as desigualdades fáticas, visando estabelecer maiores restrições à autonomia do fornecedor pelo fato de que o consumidor não teria como fixá-las em uma relação concreta. ${ }^{16}$

No entanto, o Ministro Nelson Jobim salienta que o Sistema Financeiro Nacional possui uma estrutura completamente diversa, pois o objetivo, segundo o Ministro, é a proteção da população (e não do indivíduo como consumidor isolado), mediante uma política de acompanhamento e controle da economia. ${ }^{17}$

Os bancos nasceram da aproximação de agentes econômicos deficitários (que necessitam de crédito) e de agentes econômicos superavitários (que possuem capital sobrando), realizando, assim, a intermediação financeira. Com isso, os recursos que sobrassem dos superavitários puderam ser utilizados pelos agentes deficitários, proporcionando a circulação monetária e permitindo a transformação da poupança em investimento, facilitando a produção de bens e serviços mediante o abastecimento de recursos aos produtores e fabricantes, tornando viáveis o crescimento e o desenvolvimento econômico. $^{18}$

Com efeito, os bancos fazem parte da política monetária do país, na medida em que usam como referencial para estipular sua a taxa de juros (a taxa de juros de mercado) a

\footnotetext{
${ }^{15}$ Cf. SUPREMO TRIBUNAL FEDERAL. Plenário. ADI n. 2.951-DF. Relator Ministro Carlos Velloso. Voto do Ministro Nelson Jobim. Últimas Notícias (STF). Disponível em: <http://www.stf.gov.br>. Acesso em 01.06.2006.

${ }^{16}$ Cf. SUPREMO TRIBUNAL FEDERAL. Plenário. ADI n. 2.951-DF. Relator Ministro Carlos Velloso. Voto do Ministro Nelson Jobim. Últimas Notícias (STF). Disponível em: <http://www.stf.gov.br>. Acesso em 01.06.2006.

${ }^{17}$ Cf. SUPREMO TRIBUNAL FEDERAL. Plenário. ADI n. 2.951-DF. Relator Ministro Carlos Velloso. Voto do Ministro Nelson Jobim. Últimas Notícias (STF). Disponível em: <http://www.stf.gov.br>. Acesso em 01.06.2006.

${ }^{18}$ Cf. SUPREMO TRIBUNAL FEDERAL. Plenário. ADI n. 2.951-DF. Relator Ministro Carlos Velloso. Voto do Ministro Nelson Jobim. Últimas Notícias (STF). Disponível em: <http://www.stf.gov.br>. Acesso em 01.06.2006.
} 
taxa de juros básica, estipulada por um órgão do Estado - o Comitê de Política Monetária (COPOM), junto ao Banco Central. ${ }^{19}$

A taxa de juros básica, como ressalta o Ministro Nelson Jobim, é um instrumento utilizado para definir a política monetária do país. Com ela, decide-se mediante uma escolha de Governo se haverá crescimento econômico acelerado (taxas de juros reduzidas) ou controle inflacionário rígido (taxas de juros elevadas). Cabe ao Governo encontrar o ponto de equilíbrio: uma taxa de juros que sustente um controle inflacionário e que permita um crescimento sustentável da economia. ${ }^{20}$

Nessa perspectiva, a taxa de juros de mercado não leva em conta as relações pessoais (clientes e banco), mas uma relação de perspectiva objetiva-institucional, que coloca percentuais para a cobrança do valor estipulado, tais como contingências, custos operacionais, risco, lucro e o custo de oportunidade (custo alternativo de investir o capital em qualquer outro negócio). A partir daqui, é necessário analisar o Spread bancário.

Spread bancário constitui-se na diferença entre as taxas de empréstimo praticadas pelos agentes financeiros em relação aos tomadores de crédito e a taxa de captação dessas instituições financeiras, refletindo o custo operacional dos agentes financeiros, o lucro e o risco (a taxa média de inadimplência), visando, assim, cobrir as despesas das operações de intermediação financeira, proporcionando uma margem líquida para o intermediário financeiro. $^{21}$

Nesse contexto, o jornal Valor Econômico publicou um estudo realizado pela FIPECAFI sobre a composição do Spread bancário no Brasil, em que se constata a seguinte distribuição percentual: Inadimplência - 13\%; Despesas com pessoal - 10\%; Despesas estruturais - 24\%; Tributos - 08\%; Custos de captação (juros aos aplicadores) - 36\%; Lucro líquido - 09\%.

Com efeito, o Ministro Nelson Jobim elaborou em seu voto uma "fórmula" de composição da Taxa de Juros de financiamento ao mutuário (TJM), a qual é formada pela

${ }^{19}$ Cf. SUPREMO TRIBUNAL FEDERAL. Plenário. ADI n. 2.951-DF. Relator Ministro Carlos Velloso. Voto do Ministro Nelson Jobim. Últimas Notícias (STF). Disponível em: <http://www.stf.gov.br>. Acesso em 01.06.2006.

${ }^{20}$ Cf. SUPREMO TRIBUNAL FEDERAL. Plenário. ADI n. 2.951-DF. Relator Ministro Carlos Velloso. Voto do Ministro Nelson Jobim. Últimas Notícias (STF). Disponível em: <http://www.stf.gov.br>. Acesso em 01.06.2006.

${ }^{21}$ Cf. SUPREMO TRIBUNAL FEDERAL. Plenário. ADI n. 2.951-DF. Relator Ministro Carlos Velloso. Voto do Ministro Nelson Jobim. Últimas Notícias (STF). Disponível em: <http://www.stf.gov.br>. Acesso em 01.06.2006. 
soma da taxa de juros básica (Selic) e o Spread bancário. Ressalta ainda que a parcela significativa de juros do banco é determinada pela taxa de juros básica, motivo pelo qual defende que a relação do banco com o poupador e o mutuário integra a política econômica, extravasando os limites de uma relação subjetiva. ${ }^{22}$

Assim, o Ministro Nelson Jobim separa as operações bancárias - justamente as atividades ligadas à intermediação econômica e à circulação da moeda - dos serviços bancários, atividades consideradas não típicas, não atreladas à política monetária, e que possuem regime próprio de proteção (no caso o CDC). ${ }^{23}$

\subsection{O Voto do Ministro Eros Grau}

O Ministro Eros Grau ilumina seu voto com os mandamentos constitucionais da razoabilidade e da proporcionalidade, definindo-os não apenas como princípios jurídicos, mas como postulados normativos norteadores da interpretação do Direito. ${ }^{24}$ Nessa perspectiva, repudia a atuação do requerente em querer que o STF, mediante a atuação de "legislador positivo” inove na legislação consumeirista, a fim de “corrigir” o legislador, uma vez que tal ação feriria o princípio da harmonia e do equilíbrio entre os Poderes (CF, art. $\left.2^{\circ}\right){ }^{25}$

Com efeito, o Ministro assevera que os encargos e obrigações impostos pelo CDC às instituições financeiras (referentes às relações de prestação de serviços destas com os clientes) poderiam ser definidos em lei ordinária, pelo fato da Lei Complementar estar intimamente ligada à regulamentação do sistema como um todo.

A propósito, salienta o Ministro que o Conselho Monetário Nacional - no exercício de sua capacidade normativa de conjuntura - é competente apenas para dispor sobre o desempenho de suas atividades pelas instituições financeiras, segundo a interpretação do art. $4^{\text {' }}$, VIII, da Lei n. 4.595/64. E nesse sentido, o Ministro insiste no ponto de que "a expedição

\footnotetext{
${ }^{22}$ Cf. SUPREMO TRIBUNAL FEDERAL. Plenário. ADI n. 2.951-DF. Relator Ministro Carlos Velloso. Voto do Ministro Nelson Jobim. Últimas Notícias (STF). Disponível em: <http://www.stf.gov.br>. Acesso em 01.06.2006.

${ }^{23}$ Cf. SUPREMO TRIBUNAL FEDERAL. Plenário. ADI n. 2.951-DF. Relator Ministro Carlos Velloso. Voto do Ministro Nelson Jobim. Últimas Notícias (STF). Disponível em: <http://www.stf.gov.br>. Acesso em 01.06.2006.

${ }^{24}$ Cf. sobre o assunto ÁVILA, Humberto Bergmann. Teoria dos princípios: da definição à aplicação dos princípios jurídicos. 3. ed., aumentada. São Paulo: Malheiros Editores, 2004.

${ }^{25}$ Cf. SUPREMO TRIBUNAL FEDERAL. Plenário. ADI n. 2.951-DF. Relator Ministro Carlos Velloso. Voto do Ministro Eros Grau. Últimas Notícias (STF). Disponível em: <http://www.stf.gov.br>. Acesso em 01.06.2006.
} 
de atos normativos pelo Banco Central, quando não respeitem ao funcionamento das instituições financeiras, é abusiva, consubstancia afronta desmedida à legalidade”, em razão do Conselho Monetário Nacional não possuir capacidade normativa de conjuntura em relação a outras matérias senão o funcionamento das instituições financeiras, como é o caso da Resolução n. 2.878, de 26.07.2001 (alterada pela Resolução n. 2.892, de 27.09.2001), que disciplina a proteção do consumidor em relação aos serviços prestados pelas instituições financeiras. $^{26}$

A esse respeito, o professor Paulo Roque Khouri possui entendimento no sentido de que o CDC é aplicado como legislação especial (na medida em que as relações jurídicas forem caracterizadas como relações de consumo) e não devido ao objeto da relação jurídica em si, mas em razão da natureza dos sujeitos de direito envolvidos: fornecedor de produtos ou serviços e consumidores finais, pois o CDC visa justamente regular o equilíbrio das relações entre fornecedores e consumidores (CDC, art. $4^{\circ}$, caput, III), em razão de sua vulnerabilidade (CDC, art. $4^{\mathrm{o}}$, caput, I). ${ }^{27}$

Nessa perspectiva, o Ministro Eros Grau caracteriza nitidamente a relação entre banco e cliente como uma relação de consumo, em virtude das disposições contidas nos arts. $2^{\circ}$ e $3^{\circ}$, $\S \S 1^{\circ}$ e $2^{\circ}$ do CDC:

Art. $2^{\circ}$ Consumidor é toda a pessoa física ou jurídica que adquire ou utiliza produto ou serviço como destinatária final. [...]

Art. $3^{\circ}$ Fornecedor é toda a pessoa física ou jurídica, pública ou privada, nacional ou estrangeira, bem como os entes despersonalizados, que desenvolvem atividades de produção, montagem, criação, construção, transformação, importação, exportação, distribuição ou comercialização de produtos ou prestação de serviços.

$\S 1^{\circ}$ Produto é qualquer bem, móvel ou imóvel, material ou imaterial.

$\S 2^{\circ}$ Serviço é qualquer atividade fornecida no mercado de consumo, mediante remuneração, inclusive as de natureza bancária, financeira, de crédito e securitária, salvo as decorrentes das relações de caráter trabalhista.”

Assim sendo, para os efeitos do CDC, consumidor é toda a pessoa física ou jurídica que utiliza, como destinatário final, de atividade bancária, financeira e de crédito, de

\footnotetext{
${ }^{26}$ Cf. SUPREMO TRIBUNAL FEDERAL. Plenário. ADI n. 2.951-DF. Relator Ministro Carlos Velloso. Voto do Ministro Eros Grau. Últimas Notícias (STF). Disponível em: <http://www.stf.gov.br>. Acesso em 01.06.2006.

${ }^{27}$ Cf. KHOURI, Paulo Roberto Roque Antonio. Direito do Consumidor: contratos, responsabilidade civil e defesa do consumidor em juízo. 2. ed. São Paulo: Atlas, 2005.
} 
modo que todas as instituições financeiras estão sujeitas ao cumprimento dos dispositivos estatuídos pela legislação consumeirista. ${ }^{28}$

O Ministro Eros Grau ressalta em um ponto de seu voto que o $\S 2^{\circ}$ do art. $3^{\circ}$ do CDC deve ser interpretado de acordo com a Constituição, em especial no que se refere ao “custo das operações ativas e da remuneração das operações passivas praticadas por instituições financeiras na exploração da intermediação de dinheiro na economia”. A esse respeito, segundo o Ministro, quem deve dispor sobre essa matéria é o Poder Executivo, principalmente porque incumbe a ele fiscalizar as operações de natureza financeira, o que envolve a fixação da taxa base de juros praticável no mercado financeiro. ${ }^{29}$

O Ministro defende que a fixação da taxa de juros deve ser operada em uma perspectiva macroeconômica, em razão da multiplicação da moeda circulante em moeda escritural, a qual é feita com o capital depositado nos bancos, sendo este emprestado, com reserva de determinado valor (o encaixe bancário) para o saque dos clientes, em que o capital emprestado retorna ao banco via novo depósito, sendo novamente emprestado e novamente retornando em forma de depósito. Toda essa operação é feita com um único capital, gerando a “moeda bancária”, concretizando-se apenas nos dados estatísticos dos livros bancários. ${ }^{30}$

Com efeito, essa multiplicação de moeda produzida pelos bancos gera efeitos sensíveis, principalmente quando a taxa de juros é elevada, pois altas taxas de juros incidindo sobre uma base de depósito (inúmeras vezes multiplicada) conseguem gerar um lucro altíssimo dos bancos. Para o consumidor, a taxa de juros pode chegar a $170 \%$ ao ano. ${ }^{31}$

Dentro desse contexto, para o Ministro Eros Grau:

[...] essa poderosa capacidade de criação de riqueza abstrata não pode ficar sujeita a administração desde a perspectiva das relações microeconômicas, sob pena do comprometimento dos objetivos que o artigo 192 da

\footnotetext{
${ }^{28}$ Cf. SUPREMO TRIBUNAL FEDERAL. Plenário. ADI n. 2.951-DF. Relator Ministro Carlos Velloso. Voto do Ministro Eros Grau. Últimas Notícias (STF). Disponível em: <http://www.stf.gov.br>. Acesso em 01.06.2006.

${ }^{29}$ Cf. SUPREMO TRIBUNAL FEDERAL. Plenário. ADI n. 2.951-DF. Relator Ministro Carlos Velloso. Voto do Ministro Eros Grau. Últimas Notícias (STF). Disponível em: <http://www.stf.gov.br>. Acesso em 01.06.2006.

${ }^{30}$ Cf. SUPREMO TRIBUNAL FEDERAL. Plenário. ADI n. 2.951-DF. Relator Ministro Carlos Velloso. Voto do Ministro Eros Grau. Últimas Notícias (STF). Disponível em: <http://www.stf.gov.br>. Acesso em 01.06.2006.

${ }^{31}$ Cf. SUPREMO TRIBUNAL FEDERAL. Plenário. ADI n. 2.951-DF. Relator Ministro Carlos Velloso. Voto do Ministro Eros Grau. Últimas Notícias (STF). Disponível em: <http://www.stf.gov.br>. Acesso em 01.06.2006.
} 
Constituição visa a realizar, o desenvolvimento equilibrado do país e a satisfação do interesse da coletividade. ${ }^{32}$

Assim sendo, demonstra o Ministro ser indispensável o controle efetivo da composição da taxa de juros praticada no mercado, pois acaba se instalando - de maneira visível - uma relação de dominação, cujo pólo ativo é composto pelos bancos, e o pólo passivo por diversos tipos de devedor - consumidor, micro e pequenas empresas, dentre outros. $^{33}$

A exceção da definição do custo das operações ativas e remuneração das operações passivas praticadas por instituições financeiras, em virtude da captação de dinheiro na economia, "tudo quanto exceda a taxa base de juros, os percentuais que a ela são adicionados e findam por compor o spread bancário, tudo isso pode e deve ser controlado pelo Banco Central e, se for o caso, pelo Poder Judiciário”. Pois o que excede a taxa SELIC segundo o Ministro - é relação contratual, devendo incidir o Código Civil, no que diz respeito à abusividade e à oneração excessiva por parte dos contratos.

\section{A Taxa de Juros e O STF}

Desde a promulgação da Constituição de 1988, o STF é chamado a decidir sobre a questão da taxa de juros, dispositivo antes previsto no $\S 3^{\circ}$ do art. 192. A partir da decisão proferida na ADI n. 04 (07.03.1991), o STF “consolidou” seu posicionamento no Enunciado n. 648, no sentido de que a eficácia e a aplicabilidade da norma de limitação dos juros reais necessitam de complementação legislativa.

Com efeito, antes da EC n. 40, de 2003, o STF adotava a seguinte linha de julgamento, como se depreende de alguns julgados:

Juros. Art. 192, § $3^{\circ}$, da Constituição Federal. Auto-aplicabilidade. Ao julgar a ADI 4, o Supremo Tribunal Federal entendeu que o $\S 3^{\circ}$ do art. 192 da Constituição Federal não era auto-aplicável.”34

\footnotetext{
${ }^{32}$ Cf. SUPREMO TRIBUNAL FEDERAL. Plenário. ADI n. 2.951-DF. Relator Ministro Carlos Velloso. Voto do Ministro Eros Grau. Últimas Notícias (STF). Disponível em: <http://www.stf.gov.br>. Acesso em 01.06.2006.

${ }^{33}$ Cf. SUPREMO TRIBUNAL FEDERAL. Plenário. ADI n. 2.951-DF. Relator Ministro Carlos Velloso. Voto do Ministro Eros Grau. Últimas Notícias (STF). Disponível em: <http://www.stf.gov.br>. Acesso em 01.06.2006.

${ }^{34}$ Cf. SUPREMO TRIBUNAL FEDERAL. RE n. 387.404. Relator para acórdão Ministro Joaquim Barbosa, DJ 26.03.2004. Disponível em: <http://www.stf.gov.br>. Acesso em 04.06.2006.
} 
"Mandado de injunção e taxa de juros reais. [...] A regra inscrita no art. 192, $\S 3^{\circ}$, da Constituição, por não se revestir de suficiente densidade normativa, reclama, para efeito de sua integral aplicabilidade, a necessária intervenção concretizadora do Congresso Nacional, cuja prolongada inércia - sobre transgredir, gravemente, o direito dos devedores à prestação legislativa prevista na Lei Fundamental - também configura injustificável e inconstitucional situação de mora imputável ao Poder Legislativo da União. ${ }^{35}$

Nesse contexto, sobre a fixação da taxa de juros, depreende-se dos julgados que essa matéria é competência do Poder Legislativo da União. No entanto, porque as taxas de juros são editadas pelo Poder Executivo?

O STF enfrentou na Primeira Turma uma matéria polêmica a respeito desse assunto. No Recurso Extraordinário n. 286.963-MG, cujo relator era o Ministro Sepúlveda Pertence, a Turma iniciou julgamento do RE interposto pelo Banco do Brasil em que se pretendia desconstituir acórdão que determinara a redução dos juros em $12 \%$ (consoante o disposto no Decreto n. 22.626/33) por entender que a parte da Lei n. 4.595/64 que outorga poderes ao Conselho Monetário Nacional para dispor sobre a taxa de juros bancários não estaria recepcionada materialmente pela Constituição de 1988, segundo a redação do art. 25 do Ato das Disposições Constitucionais Transitórias (ADCT), razão pela qual a Lei de Usura voltaria a viger em sua integralidade (por meio de uma repristinação devido a recepção material em relação ao conteúdo da Constituição atual). ${ }^{36}$

Nesse aspecto, os efeitos práticos de uma decisão que negasse provimento ao RE seriam apenas a declaração de inconstitucionalidade de todas as operações financeiras a partir de 06 de maio de 1989, com fundamento no art. 25 do ADCT. Dispõe o aludido dispositivo:

Art. 25. Ficam revogados, a partir de cento e oitenta dias da promulgação da Constituição, sujeito esse prazo a prorrogação por lei, todos os dispositivos legais que atribuam ou deleguem a órgão do Poder Executivo competência assinalada pela Constituição ao Congresso Nacional, especialmente no que tange à:

I - ação normativa;

II - alocação ou transferência de recursos de qualquer espécie.

35 Cf. SUPREMO TRIBUNAL FEDERAL. Plenário. MI n. 542. Relator Ministro Celso de Mello, DJ 28.06.2002. Disponível em: <http://www.stf.gov.br>. Acesso em 01.06.2006.

${ }^{36}$ Cf. SUPREMO TRIBUNAL FEDERAL. 1. Turma. RE n. 286.963-MG. Relator Ministro Sepúlveda Pertence. Informativo (STF) n. 381. Disponível em: <http://www.stf.gov.br>. Acesso em 04.06.2006. 
Em seu voto, o Ministro Sepúlveda Pertence entendeu não existir a revogação da Lei n. 4.595/64 por o objeto de revogação - quando ultrapassado o prazo de 180 dias da promulgação da Constituição - ser a competência atribuída ou delegada a órgão do Poder Executivo pela legislação pré-constitucional (quando se tratar de matéria incluída na competência do Congresso Nacional), e não as normas editadas quando vigente a delegação, sendo indiferente, para sua observância, ter ou não havido a prorrogação prevista no art. 25 do ADCT. ${ }^{37}$

O julgamento estava com o score de 03 votos a favor da tese postulada pelo Requerente (pois acompanharam o voto do Relator os Ministros Carlos Britto e Eros Grau), quando o Ministro Marco Aurélio pediu vista dos autos.

No retorno de seu voto-vista (03.05.2005), o Ministro Marco Aurélio propôs a remessa dos autos ao Plenário - conforme o RISTF - a fim de se examinar a constitucionalidade da Lei n. 9.069/95 (lei que institui o Plano Real, e dispõe sobre o Sistema Financeiro Nacional), sendo a proposta rejeitada. ${ }^{38}$

Prosseguindo em seu voto-vista, negou provimento ao RE, asseverando que se trata do exame da constitucionalidade da delegação prevista para que o Conselho Monetário Nacional fixe juros para o sistema financeiro. Com efeito, após fazer histórico das leis que prorrogam a delegação de 180 dias do ADCT, art. 25, culminando no advento da Lei n. 9.069/95, entendeu que esta sucessão de delegações conflita com o espírito do conteúdo do art. 25 do ADCT, em razão da ausência da razoabilidade na prorrogação de leis que elastecem de forma indiscriminada o prazo de 180 dias. $^{39}$

Destarte, o Ministro Marco Aurélio ressaltou ainda que passados mais de 16 anos da vigência da Constituição de 1988, a competência do Conselho Monetário Nacional (que determina a base de todas as relações jurídicas no plano do sistema financeiro) se fundamenta em uma extravagante delegação. Por essa razão, o Ministro Marco Aurélio declarou a

\footnotetext{
${ }^{37}$ Cf. SUPREMO TRIBUNAL FEDERAL. 1. Turma. RE n. 286.963-MG. Relator Ministro Sepúlveda Pertence. Informativo (STF) n. 381. Disponível em: <http://www.stf.gov.br>. Acesso em 04.06.2006.

${ }^{38}$ Cf. SUPREMO TRIBUNAL FEDERAL. 1. Turma. RE n. 286.963-MG. Relator Ministro Sepúlveda Pertence. Informativo (STF) n. 386. Disponível em: <http://www.stf.gov.br>. Acesso em 04.06.2006.

${ }^{39}$ Cf. SUPREMO TRIBUNAL FEDERAL. 1. Turma. RE n. 286.963-MG. Relator Ministro Sepúlveda Pertence. Informativo (STF) n. 386. Disponível em: <http://www.stf.gov.br>. Acesso em 04.06.2006.
} 
inconstitucionalidade da última lei (a Lei n. 9.069/95) que implicou na prorrogação do prazo de 180 dias (referente ao ADCT, art. 25). ${ }^{40}$

Dentro desse contexto, o Ministro Marco Aurélio, em plena sessão, conseguiu convencer o Ministro Carlos Britto, o qual concordou com os argumentos postos, fazendo com que o score saísse de 03 votos a zero para o empate (02 votos a 02).

A partir daí, houve uma intensa discussão entre os Ministros Sepúlveda Pertence, Eros Grau, de um lado, e Marco Aurélio e Carlos Britto de outro, no sentido de que se o entendimento do Ministro Marco Aurélio fosse levado à frente, instalar-se-ia a "teoria do caos”. Tanto o Ministro Marco Aurélio, como o Ministro Carlos Britto, asseveram que cabe ao Congresso Nacional observar o postulado da razoabilidade e editar as normas que regulam o sistema, não deixando aos fatores econômicos o comando da estrutura do ordenamento jurídico.

De forma serena, o Ministro Cezar Peluso pediu vista dos autos e, ao retornar com estes (em 24.05.2005), optou em não instalar a "teoria do caos”, seguindo os fundamentos do voto do Relator, “mantendo as coisas como elas estão”.

Após a análise estrutural da jurisprudência do STF, é importante iluminar (mesmo que de maneira propedêutica) os argumentos constantes dessa jurisprudência sobre o enfoque da eficácia dos direitos fundamentais nas relações jurídico-privadas.

\section{A Aplicação Da Teoria Da Eficácia Dos Direitos Fundamentais Nas Relações Entre Particulares}

\subsection{Prolegômenos}

Bianca Rodriguez Ruiz retrata muito bem a dificuldade em encontrar uma justificativa teórica plausível para a aplicação dos direitos fundamentais nas relações entre particulares, no que diz respeito principalmente à atuação dos direitos fundamentais como escudo frente às intromissões de um poder político artificial no âmbito de uma sociedade civil concebida naturalmente. ${ }^{41}$

\footnotetext{
${ }^{40}$ Cf. SUPREMO TRIBUNAL FEDERAL. 1. Turma. RE n. 286.963-MG. Relator Ministro Sepúlveda Pertence. Informativo (STF) n. 386. Disponível em: <http://www.stf.gov.br>. Acesso em 04.06.2006.

${ }^{41}$ Cf. RODRIGUEZ RUIZ, Bianca. Resenha do livro de NARANJO DE LA CRUZ, Rafael. Los límites de los derechos y fundamentales en las relaciones entre particulares: la buena fe. Madrid: Centros de Estudios Políticos y Constitucionales, 2000. In: Teoría y realidad constitucional, n. 10-11, p. 792-798, 2003 , p. 792.
} 
Com efeito, as bases do Estado Constitucional parecem estar fixadas no ideal do contrato social: direitos fundamentais são indicados para articular as relações (cada vez mais complexas) do poder político com a sociedade civil. ${ }^{42}$

No contexto atual do século XXI, percebem-se feições específicas e diferenciadas entre direitos fundamentais e o direito privado. A eficácia horizontal dos direitos fundamentais nas relações privadas nada mais é do que a vinculação das pessoas naturais ou jurídicas aos direitos fundamentais. ${ }^{43}$

Desse modo, discute-se a existência de duas perspectivas para a eficácia horizontal: (a) material, que trata da existência ou não de uma vinculação dos sujeitos particulares aos direitos fundamentais, estabelecendo-se a amplitude dessa vinculação; e (b) processual, no que diz respeito aos meios para tornar os direitos fundamentais efetivos nas relações interprivadas, ou seja, a possibilidade de um particular (CONSUMIDOR), via ação judicial, opor-se diretamente a eventual violação de seu direito fundamental por parte de outro particular (BANCOS). ${ }^{44}$

Nesse sentido, Ingo Sarlet discute até que ponto um particular pode opor seu direito fundamental a outro particular, pois ambos, envolvidos em uma determinada relação jurídica, são titulares de direitos fundamentais. ${ }^{45}$

Para isso, o autor importa da discussão alemã duas teorias - a eficácia imediata e a mediata. ${ }^{46}$ A primeira visa evitar a segregação da ordem privada, em obediência aos

Disponível em: <http://www.juridicas.unam.mx/publica/librev/rev/trcons/cont/10/rec/rec35.pdf>. Acesso em: 25.10.2005.

${ }^{42}$ Cf. RODRIGUEZ RUIZ, Bianca. Resenha do livro de NARANJO DE LA CRUZ, Rafael. Los límites de los derechos y fundamentales en las relaciones entre particulares: la buena fe. Madrid: Centros de Estudios Políticos y Constitucionales, 2000. In: Teoría y realidad constitucional, n. 10-11, p. 792-798, 2003, p. 792. Disponível em: <http://www.juridicas.unam.mx/publica/librev/rev/trcons/cont/10/rec/rec35.pdf>. Acesso em: 25.10.2005.

${ }^{43}$ Cf. SARLET, Ingo Wolfgang. Direitos Fundamentais e Direito Privado: algumas considerações em torno da vinculação dos particulares aos direitos fundamentais. In: Revista de Direito do Consumidor, São Paulo: Revista dos Tribunais, n. 36, p. 54-103, out./dez. 2000, p. 55-56.

${ }^{44}$ Cf. SARLET, Ingo Wolfgang. Direitos Fundamentais e Direito Privado: algumas considerações em torno da vinculação dos particulares aos direitos fundamentais. In: Revista de Direito do Consumidor, São Paulo: Revista dos Tribunais, n. 36, p. 54-103, out./dez. 2000, p. 56-57.

${ }^{45}$ Cf. SARLET, Ingo Wolfgang. Direitos Fundamentais e Direito Privado: algumas considerações em torno da vinculação dos particulares aos direitos fundamentais. In: Revista de Direito do Consumidor, São Paulo: Revista dos Tribunais, n. 36, p. 54-103, out./dez. 2000, p. 58-61.

${ }^{46}$ É importante destacar a observação de Rogério Magnus Varela Gonçalves, no sentido de que se deve analisar o caso concreto para vislumbrar o equilíbrio de forças entre os particulares e a partir desse ponto definir sobre a validade automática ou diferida dos direitos fundamentais (cf. GONÇALVES, Rogério Magnus Varela. Os direitos fundamentais e sua validade no âmbito das relações privadas. Prim@ Facie: Revista da PósGraduação Ciências Jurídicas - Universidade Federal da Paraíba, a. 03, n. 5, p. 73-110, jul./dez. 2004, p. 89. Disponível em: <http://www.ccj.ufpb.br/primafacie/prima/artigos/n5/direitos.pdf>. Acesso em: 29.06.2006). 
princípios da unidade e da força normativa da Constituição. ${ }^{47}$ Pela segunda, o efeito irradiante dos direitos fundamentais seria realizado, na ausência de normas jurídicas privadas, de forma indireta, mediante a interpretação e a integração das “cláusulas gerais”48 e conceitos indeterminados do direito privado à luz dos direitos fundamentais. ${ }^{49}$

Nesse sentido, um paradoxo se apresenta, pois a eficácia indireta dos direitos fundamentais segue o contorno ideal do contrato social, uma vez que por intermédio do legislador se efetiva os direitos fundamentais nas relações privadas. No entanto, descartar a eficácia direta seria por em discussão o caráter normativo da Constituição em relação ao direito privado, correndo o risco de assumir os direitos fundamentais apenas como normas programáticas no âmbito das relações privadas. ${ }^{50}$

Destarte, as relações entre indivíduos e detentores de poder social geram um desequilíbrio, o qual enseja uma vinculação direta do tipo eficácia vertical (semelhante ao Estado) no que diz respeito à aplicação dos direitos fundamentais. No entanto, o indivíduo, além de ser objeto de atores sociais poderosos, integra algumas organizações, a fim de proteger seus interesses. $^{51}$

Nesse sentido, as agressões a direitos fundamentais, no âmbito das relações jurídicas privadas, partem diretamente de um particular, os quais atuam em virtude de uma decisão independente, no âmbito de sua autonomia privada e no exercício do direito de liberdade. Desse modo, em um conflito entre particulares, todos gozam de proteção dos direitos fundamentais, com uma espécie de atuação simultânea - ora contra, ora a favor.

47 Cf. SILVA, Christine Oliveira Peter da. Hermenêutica constitucional e os princípios norteadores da concretização das normas constitucionais. Notícias do Direito Brasileiro. Brasília: UnB, n. 09, p. 155-175, 2002.

${ }^{48}$ Cláusulas gerais consistem em disposições jurídico-privadas, de cunho imperativo, que são a ponte pela qual atravessa os direitos fundamentais, ingressando no direito privado (cf. SARLET, Ingo Wolfgang. Direitos Fundamentais e Direito Privado: algumas considerações em torno da vinculação dos particulares aos direitos fundamentais. In: Revista de Direito do Consumidor, São Paulo: Revista dos Tribunais, n. 36, p. 54-103, out./dez. 2000, p. 67-70).

${ }^{49}$ Cf. SARLET, Ingo Wolfgang. Direitos Fundamentais e Direito Privado: algumas considerações em torno da vinculação dos particulares aos direitos fundamentais. In: Revista de Direito do Consumidor, São Paulo: Revista dos Tribunais, n. 36, p. 54-103, out./dez. 2000, p. 58-61.

${ }^{50}$ No âmbito dessa discussão, os Tribunais Constitucionais apresentam esse dilema em sua atuação, no sentido de aplicarem (ou não) os direitos fundamentais entre os particulares de maneira imediata a fim de sanar eventual omissão legislativa crônica (cf. RODRIGUEZ RUIZ, Bianca. Resenha do livro de NARANJO DE LA CRUZ, Rafael. Los límites de los derechos y fundamentales en las relaciones entre particulares: la buena fe. Madrid: Centros de Estudios Políticos y Constitucionales, 2000. In: Teoría y realidad constitucional, n. 10-11, p. 792-798, 2003, p. $792 . \quad$ Disponível em: <http://www.juridicas.unam.mx/publica/librev/rev/trcons/cont/10/rec/rec35.pdf>. Acesso em: 25.10.2005).

${ }^{51}$ Cf. SARLET, Ingo Wolfgang. Direitos Fundamentais e Direito Privado: algumas considerações em torno da vinculação dos particulares aos direitos fundamentais. In: Revista de Direito do Consumidor, São Paulo: Revista dos Tribunais, n. 36, p. 54-103, out./dez. 2000, p. 73-74. 
Nessa hipótese, cabe à legislação a composição, a busca pela ponderação e pelo ponto de equilíbrio. Assim sendo, o caráter indeterminado e abstrato, e o suposto risco de esvaziar a autonomia privada não podem ser justificativa para impedir a vinculação dos particulares aos direitos fundamentais. ${ }^{52}$

5.2 O papel da dignidade da pessoa humana e da boa-fé no exercício dos direitos fundamentais nas relações entre particulares

A justificativa para a eficácia imediata dos direitos fundamentais está no fato de que o Estado Constitucional Contemporâneo estrutura-se na tutela da dignidade e da liberdade da pessoa (conceito mais amplo e complexo do que a autonomia da vontade na qual se funda o Estado Liberal). ${ }^{53}$

Com efeito, a dignidade e a liberdade da pessoa humana estão armazenadas no seio da sociedade, e por essa razão o respeito e a proteção desses valores exigem que os direitos fundamentais nos quais elas se fundamentam possam se fazer valer frente aos particulares. ${ }^{54}$

Situar a tutela da dignidade da pessoa humana no núcleo essencial dos direitos fundamentais tem sido uma constante no constitucionalismo pós-moderno. ${ }^{55}$ Nesse sentido, Leonardo Martins - ao estudar a literatura especializada alemã e os casos julgados pelo

52 Cf. SARLET, Ingo Wolfgang. Direitos Fundamentais e Direito Privado: algumas considerações em torno da vinculação dos particulares aos direitos fundamentais. In: Revista de Direito do Consumidor, São Paulo: Revista dos Tribunais, n. 36, p. 54-103, out./dez. 2000, p. 82-88.

${ }^{53}$ Cf. RODRIGUEZ RUIZ, Bianca. Resenha do livro de NARANJO DE LA CRUZ, Rafael. Los límites de los derechos y fundamentales en las relaciones entre particulares: la buena fe. Madrid: Centros de Estudios Políticos y Constitucionales, 2000. In: Teoría y realidad constitucional, n. 10-11, p. 792-798, 2003 , p. 794. Disponível em: <http://www.juridicas.unam.mx/publica/librev/rev/trcons/cont/10/rec/rec35.pdf>. Acesso em: 25.10.2005.

${ }^{54}$ Cf. RODRIGUEZ RUIZ, Bianca. Resenha do livro de NARANJO DE LA CRUZ, Rafael. Los límites de los derechos y fundamentales en las relaciones entre particulares: la buena fe. Madrid: Centros de Estudios Políticos y Constitucionales, 2000. In: Teoría y realidad constitucional, n. 10-11, p. 792-798, 2003, p. 794. Disponível em: <http://www.juridicas.unam.mx/publica/librev/rev/trcons/cont/10/rec/rec35.pdf>. Acesso em: 25.10.2005.

${ }^{55}$ Cf. RODRIGUEZ RUIZ, Bianca. Resenha do livro de NARANJO DE LA CRUZ, Rafael. Los límites de los derechos y fundamentales en las relaciones entre particulares: la buena fe. Madrid: Centros de Estudios Políticos y Constitucionales, 2000. In: Teoría y realidad constitucional, n. 10-11, p. 792-798, 2003 , p. 794. Disponível em: <http://www.juridicas.unam.mx/publica/librev/rev/trcons/cont/10/rec/rec35.pdf>. Acesso em: 25.10.2005. 
Tribunal Constitucional Federal (TCF) alemão - observa que boa parte dos direitos fundamental possui em seu conteúdo a garantia da dignidade da pessoa humana. ${ }^{56}$

No entanto, a definição do que seja dignidade humana é um dos temas mais complexos de toda a doutrina. Na literatura especializada alemã, por exemplo, muitos são os pontos de ênfase e formas de tratamento da matéria, preferindo-se, então, se preocupar com uma definição negativa do preceito, ou seja, saber quando há uma intervenção ou violação da dignidade da pessoa humana, gerando como conseqüência uma maior importância para a definição de sua área de proteção. ${ }^{57}$

Nesse sentido, Leonardo Martins apresenta decisões proferidas no contexto do TCF que visam concretizar a dignidade da pessoa humana. Dentre elas está a Reclamação Constitucional (Bverge 30, 1 - Abhörurteil), julgada em 15.12.1970, contra a Emenda Constitucional n. 17, a qual inseriu uma reserva legal que possibilitou ao legislador infraconstitucional limitar o sigilo da correspondência, da telecomunicação e postal (em suma, questionava-se a constitucionalidade da escuta telefônica). Com cinco votos contra três, o TCF declarou constitucionais todas as normas impugnadas. Todavia, a interpretação do conceito de dignidade da pessoa humana da Constituição foi decisiva para evitar a unanimidade da decisão, como se observa em um dos trechos:

O tratamento da pessoa humana pelo poder público que cumpre a lei deve, para se verificar se a dignidade humana foi atingida, ser expressão do desrespeito ao valor que o ser humano tem direito por força de sua existência como pessoa. ${ }^{58}$

Bianca Rodriguez Ruiz, por sua vez, critica o posicionamento de colocar a dignidade da pessoa humana como centro da discussão, em razão de ser uma noção demasiadamente volátil, potencialmente conservadora e culturalmente colonizadora, sendo

\footnotetext{
${ }^{56}$ Cf. MARTINS, Leonardo (org.). Cinqüenta Anos de Jurisprudência do Tribunal Constitucional Federal Alemão. Coletânea original: Jürgen Schwabe. Montevideo, Uruguay: Fundación Konrad-Adenauer, 2005, p. 178.

${ }^{57}$ MARTINS, Leonardo (org.). Cinqüenta Anos de Jurisprudência do Tribunal Constitucional Federal Alemão. Coletânea original: Jürgen Schwabe. Montevideo, Uruguay: Fundación Konrad-Adenauer, 2005, p. 177-178.

${ }^{58}$ Cf. MARTINS, Leonardo (org.). Cinqüenta Anos de Jurisprudência do Tribunal Constitucional Federal Alemão. Coletânea original: Jürgen Schwabe. Montevideo, Uruguay: Fundación Konrad-Adenauer, 2005, p. 179-180.
} 
inadequada para sustentar um Estado Constitucional tão complexo, o qual aspira a igualdade efetiva entre os indivíduos que o compõe. ${ }^{59}$

Assim, em que ficção se apóia o Estado Constitucional contemporâneo? Tal questionamento é relevante porque a fundamentação do Estado Constitucional - que aspira proteger a dignidade e a liberdade sobre a base de uma Constituição normativa - deve ser capaz de justificar e dar coerência à eficácia dos direitos fundamentais nas relações entre os particulares. Nesse sentido, tal fundamentação deve-se alojar nas premissas do contrato social entre o poder político e a sociedade civil, e não apenas nessa última. ${ }^{60}$

Dentro desse contexto, dois fundamentos alternativos da Teoria do Estado se destacam: uma de natureza teórico-discursiva, e outra de cunho autopoiético ou pós-moderno. A teoria pós-moderna concebe os direitos fundamentais como elo de conexão com sistemas públicos e privados independentes - inibindo a dominação de um sistema pelo outro - e estimulando a liberdade pessoal de atuação no seio de uma esfera social sem interferência de outra esfera, além de colocar a eficácia dos direitos fundamentais nas relações particulares em pé de igualdade com a eficácia desses direitos frente aos poderes públicos. ${ }^{61}$

Por outro lado, a teoria do discurso tem como premissas o indivíduo e as noções de igualdade e liberdade, conectadas com a tradição moderna e enfatizando o conteúdo comunicativo da modernidade, situando a liberdade, a igualdade e a concretização desses direitos fundamentais a serviço da comunicação entre os indivíduos (significando, portanto, que essa teoria assume a eficácia horizontal dos direitos fundamentais). ${ }^{62}$

\footnotetext{
${ }^{59}$ Cf. RODRIGUEZ RUIZ, Bianca. Resenha do livro de NARANJO DE LA CRUZ, Rafael. Los límites de los derechos y fundamentales en las relaciones entre particulares: la buena fe. Madrid: Centros de Estudios Políticos y Constitucionales, 2000. In: Teoría y realidad constitucional, n. 10-11, p. 792-798, 2003 , p. 794. Disponível em: <http://www.juridicas.unam.mx/publica/librev/rev/trcons/cont/10/rec/rec35.pdf>. Acesso em: 25.10.2005.

${ }^{60}$ Cf. RODRIGUEZ RUIZ, Bianca. Resenha do livro de NARANJO DE LA CRUZ, Rafael. Los límites de los derechos y fundamentales en las relaciones entre particulares: la buena fe. Madrid: Centros de Estudios Políticos y Constitucionales, 2000. In: Teoría y realidad constitucional, n. 10-11, p. 792-798, 2003, p. 795. Disponível em: <http://www.juridicas.unam.mx/publica/librev/rev/trcons/cont/10/rec/rec35.pdf>. Acesso em: 25.10.2005.

${ }^{61}$ Cf. RODRIGUEZ RUIZ, Bianca. Resenha do livro de NARANJO DE LA CRUZ, Rafael. Los límites de los derechos y fundamentales en las relaciones entre particulares: la buena fe. Madrid: Centros de Estudios Políticos y Constitucionales, 2000. In: Teoría y realidad constitucional, n. 10-11, p. 792-798, 2003 , p. 795. Disponível em: <http://www.juridicas.unam.mx/publica/librev/rev/trcons/cont/10/rec/rec35.pdf>. Acesso em: 25.10.2005.

${ }^{62}$ Cf. RODRIGUEZ RUIZ, Bianca. Resenha do livro de NARANJO DE LA CRUZ, Rafael. Los límites de los derechos y fundamentales en las relaciones entre particulares: la buena fe. Madrid: Centros de Estudios Políticos y Constitucionales, 2000. In: Teoría y realidad constitucional, n. 10-11, p. 792-798, 2003 , p. 795. Disponível em: <http://www.juridicas.unam.mx/publica/librev/rev/trcons/cont/10/rec/rec35.pdf>. Acesso em: 25.10.2005.
} 
Segundo Bianca Rodríguez, o interessante dessas concepções alternativas de Estado e de direitos fundamentais (a pós-moderna e a discursiva) é que ambas são coerentes com a existência de uma Constituição normativa, o que lhes permite formular sem distorções a eficácia entre particulares destes direitos. ${ }^{63}$

Naranjo de la Cruz, nessa perspectiva, assevera que a boa-fé nos conflitos de direitos fundamentais atua como elemento definidor, delimitador ou limitador da eficácia desses direitos, pois ela é um autêntico e indiscutível princípio geral de Direito, cuja definição essencial está em seu caráter informador do ordenamento jurídico. ${ }^{64}$

De forma concreta, a boa-fé constitui um ponto de conexão entre o Direito e as convenções gerais, uma janela aberta ao mundo das valorações sociais, que desempenha tanto funções normativas (de integração de disposições contratuais, de criação de obrigações jurídicas e de limitação de direitos subjetivos), como funções interpretativas de direitos e contratos, conectando-se com a respectiva lógica interna de cada instituto. ${ }^{65}$

Assim, as obrigações contratuais dependem da lógica interna subjetiva, institucional e social do contrato, uma vez que a boa-fé - conectada com a teoria do abuso do direito e dos limites imanentes - se erige no limite dos direitos ao impedir que estes possam ser exercidos fora de sua própria razão, entendida tanto em sua dimensão individual, como também em sua dimensão institucional e social. ${ }^{66}$

Com efeito, a boa-fé também atua na lógica interna dos direitos fundamentais, modulando a ponderação desses direitos com outros bens constitucionais, a fim de determinar

${ }^{63}$ Cf. RODRIGUEZ RUIZ, Bianca. Resenha do livro de NARANJO DE LA CRUZ, Rafael. Los límites de los derechos y fundamentales en las relaciones entre particulares: la buena fe. Madrid: Centros de Estudios Políticos y Constitucionales, 2000. In: Teoría y realidad constitucional, n. 10-11, p. 792-798, 2003, p. 796. Disponível em: <http://www.juridicas.unam.mx/publica/librev/rev/trcons/cont/10/rec/rec35.pdf>. Acesso em: 25.10.2005.

${ }^{64}$ Cf. RODRIGUEZ RUIZ, Bianca. Resenha do livro de NARANJO DE LA CRUZ, Rafael. Los límites de los derechos y fundamentales en las relaciones entre particulares: la buena fe. Madrid: Centros de Estudios Políticos y Constitucionales, 2000. In: Teoría y realidad constitucional, n. 10-11, p. 792-798, 2003, p. 796. Disponível em: <http://www.juridicas.unam.mx/publica/librev/rev/trcons/cont/10/rec/rec35.pdf>. Acesso em: 25.10.2005.

${ }^{65}$ Cf. RODRIGUEZ RUIZ, Bianca. Resenha do livro de NARANJO DE LA CRUZ, Rafael. Los límites de los derechos y fundamentales en las relaciones entre particulares: la buena fe. Madrid: Centros de Estudios Políticos y Constitucionales, 2000. In: Teoría y realidad constitucional, n. 10-11, p. 792-798, 2003, p. 796. Disponível em: <http://www.juridicas.unam.mx/publica/librev/rev/trcons/cont/10/rec/rec35.pdf>. Acesso em: 25.10.2005.

${ }^{66}$ Cf. RODRIGUEZ RUIZ, Bianca. Resenha do livro de NARANJO DE LA CRUZ, Rafael. Los límites de los derechos y fundamentales en las relaciones entre particulares: la buena fe. Madrid: Centros de Estudios Políticos y Constitucionales, 2000. In: Teoría y realidad constitucional, n. 10-11, p. 792-798, 2003 , p. 797. Disponível em: <http://www.juridicas.unam.mx/publica/librev/rev/trcons/cont/10/rec/rec35.pdf>. Acesso em: 25.10.2005. 
qual dos direitos ou bens constitucionais será aplicado em determinado caso concreto, tendo em conta a lógica tridimensional desses direitos (subjetiva, institucional e social) e os parâmetros definidores da situação concreta em análise. ${ }^{67}$

Nesse aspecto, a igualdade em sentido material e a liberdade (em um contexto relativo e crítico, que leve em conta os condicionamentos materiais, sociais e as relações entre os indivíduos) são consideradas por Bianca Rodriguez como as pedras de torque do Estado Constitucional, especialmente se combinadas, a fim de conferir igual liberdade ao indivíduo para participar em concreto das deliberações políticas e das instâncias de revisão (judicial). ${ }^{68}$

\subsection{O diálogo das fontes: a constitucionalização do direito privado no âmbito do Supremo Tribunal Federal}

A eficácia horizontal dos direitos fundamentais nas relações privadas já teve seu primeiro caso julgado na $2^{\text {a }}$ Turma da Suprema Corte. Trata-se do RE n. 201.819 - exemplo de aplicação direta dos direitos fundamentais às relações privadas - cujo resultado final (com

${ }^{67}$ Cf. RODRIGUEZ RUIZ, Bianca. Resenha do livro de NARANJO DE LA CRUZ, Rafael. Los límites de los derechos y fundamentales en las relaciones entre particulares: la buena fe. Madrid: Centros de Estudios Políticos y Constitucionales, 2000. In: Teoría y realidad constitucional, n. 10-11, p. 792-798, 2003 , p. 797. Disponível em: <http://www.juridicas.unam.mx/publica/librev/rev/trcons/cont/10/rec/rec35.pdf>. Acesso em: 25.10.2005.

${ }^{68}$ Cf. RODRIGUEZ RUIZ, Bianca. Resenha do livro de NARANJO DE LA CRUZ, Rafael. Los límites de los derechos y fundamentales en las relaciones entre particulares: la buena fe. Madrid: Centros de Estudios Políticos y Constitucionales, 2000. In: Teoría y realidad constitucional, n. 10-11, p. 792-798, 2003 , p. 794. Disponível em: <http://www.juridicas.unam.mx/publica/librev/rev/trcons/cont/10/rec/rec35.pdf>. Acesso em: 25.10.2005. Sobre a noção de igualdade e liberdade, Menelick de Carvalho Netto tem posicionamento fundamentado nos estudos de Ronald Dworkin - no sentido de que igualdade e liberdade são valores opostos (se se é igual, não se é livre, da mesma forma de que sendo livre, não se será igual). Assim, Menelick de Carvalho Netto assevera que a igualdade se consubstancia no direito à diferença, colocando-se os indivíduos em condições idênticas de atuação, trabalhando-se em conjunto com a liberdade a idéia de respeito ao outro indivíduo. No mesmo sentido se posiciona Leonardo Martins, ao utilizar os conhecimentos de Pieroth Schilink, asseverando que a liberdade e a igualdade - grandes bandeiras do movimento constitucionalista que passaram a integrar o texto das constituições ocidentais democráticas - encontram-se em eterno conflito no contexto das sociedades, pois uma se caracteriza como a liberdade concorrencial inescrupulosa do mais forte, enquanto a outra se anuncia como a igualdade de chances a ser concedida ao mais fraco. Nesse contexto, o legislador ordinário é um dos responsáveis a disciplinar o conflito social entre esses dois direitos, cabendo tanto às garantias constitucionais de igualdade quanto às de liberdade o dever de impor ao legislador limites (diminuição da liberdade ou tratamento desigual) dos quais ele não poderá ultrapassar sem um motivo racional e ponderado (cf. MARTINS, Leonardo (org.). Cinqüenta Anos de Jurisprudência do Tribunal Constitucional Federal Alemão. Coletânea original: Jürgen Schwabe. Montevideo, Uruguay: Fundación Konrad-Adenauer, 2005, p. 320). 
o voto-vista do Ministro Celso de Melo) ficou em 03 votos a 02 a favor da aplicação da teoria da eficácia horizontal. ${ }^{69}$

O Ministro Gilmar Mendes, ao proferir voto-vista, adequou a questão à teoria da eficácia dos direitos fundamentais nas relações jurídico-privadas. No mesmo sentido, o Ministro Joaquim Barbosa o fez - acompanhando o Ministro Gilmar Mendes - entendendo que os princípios fundamentais têm aplicação no âmbito das relações privadas, devendo ser aferida caso a caso, a fim de não se suprimir a autonomia privada. ${ }^{70}$

A esse respeito, a professora Cláudia Lima Marques proferiu palestra sobre a ADI n. 2.591 (a ADI dos Bancos) no IV Seminário de Direito Privado, organizado pelo IDP. Ressaltou em sua exposição a argumentação dos bancos, no sentido de que a defesa do consumidor (CF, art. 170, V) - referente ao serviço bancário (CDC, art. $3^{\circ}$, § $2^{\circ}$ ) - não lhes seria aplicada, em razão desse dispositivo estar fora do Capítulo IV (do Sistema Financeiro Nacional), não representando um valor para a Ordem Financeira. ${ }^{71}$

Com efeito, a professora destaca que implicitamente há uma discussão sobre direitos fundamentais, uma vez que o Estado (nas funções judicial, legislativa e executiva) deve promover a defesa do consumidor (CF, art. 5 , XXXII). Dentro dessa linha de argumentação, a professora questiona: como preencher esse tipo de cláusula geral (assim como a boa-fé no Código Civil, art. 421) ${ }^{72}$

Nesse contexto, a professora Cláudia Lima Marques apresenta como um dos caminhos a aplicação da teoria da eficácia dos direitos fundamentais (iluminados de forma mediata) nas relações entre particulares ${ }^{73}$, afirmando que a grande decisão do STF sobre o

${ }^{69}$ Cf. SUPREMO TRIBUNAL FEDERAL. 2. Turma. RE n. 201.819. Relatora. Ministra Ellen Gracie. Relator para o acórdão Ministro Gilmar Mendes. Informativos (STF) n.(s) 351, 370, 385 e 405. Disponível em: <http://www.stf.gov.br>. Acesso em: 20.10.2005.

${ }^{70}$ Cf. SUPREMO TRIBUNAL FEDERAL. 2. Turma. RE n. 201.819. Relatora. Ministra Ellen Gracie. Relator para o acórdão Ministro Gilmar Mendes. Informativos (STF) n.(s) 351, 370, 385 e 405. Disponível em: <http://www.stf.gov.br>. Acesso em: 20.10.2005.

${ }^{71}$ Cf. MARQUES, Cláudia Lima. Constituição, Direito Privado e o Consumidor. In: Iv Seminário De Direito Privado - A Constituição E A Vida Privada - Constituição E Pessoa Humana \& Constituição E Atividade Econômica, 22 a 24 de junho de 2006. Brasília: Instituto Brasiliense de Direito Público, 2006.

${ }^{72}$ Cf. MARQUES, Cláudia Lima. Constituição, Direito Privado e o Consumidor. In: Iv Seminário De Direito Privado - A Constituição E A Vida Privada - Constituição E Pessoa Humana \& Constituição E Atividade Econômica, 22 a 24 de junho de 2006. Brasília: Instituto Brasiliense de Direito Público, 2006.

${ }^{73}$ Nesse sentido, a professora se refere ao julgamento do RE n. 201.819 (já mencionado), em que o Ministro Gilmar Mendes conseguiu reverter um score de três votos a zero (desfavorável à aplicação da teoria da eficácia horizontal dos direitos fundamentais nas relações entre particulares) para três votos a dois - favorável à aplicação desta teoria, desde que se respeite a autonomia privada na análise de cada caso concreto (Cf. SUPREMO TRIBUNAL FEDERAL. 2. Turma. RE n. 201.819. Relatora. Ministra Ellen Gracie. Relator para o 
tema é a ADI dos Bancos ${ }^{74}$, pois indiretamente há o brilho do direito fundamental iluminando alguma proteção do consumidor. ${ }^{75}$

Nessa perspectiva, a professora destaca a constitucionalização do direito privado, na medida em que a própria Constituição de 1988 - no Ato das Disposições Constitucionais Transitórias (ADCT, art. 48) - determinou ao Congresso Nacional a elaboração do Código de Defesa do Consumidor, a fim de que o sujeito de direitos (conceito fortíssimo no Direito Privado) tenha a proteção constitucional que merece. ${ }^{76}$

Assim sendo, o CDC se apresenta ao direito privado com o "privilégio constitucional”, uma vez que acompanha a reconstrução do direito civil pela Constituição Federal, com a catalogação dos novos sujeitos de direitos (a pessoa natural, o empresário e o consumidor). E em virtude do brilho cada vez maior do direito constitucional, o CDC possibilita o link entre o direito privado e a Constituição, em um espaço onde o direito privado passa a ser coerente com os ditames constitucionais, havendo a possibilidade de interpretar o direito privado conforme a Constituição, garantindo a efetividade dos direitos fundamentais no âmbito do direito privado (eficácia horizontal dos direitos fundamentais). ${ }^{77}$

De certa maneira, a constitucionalização e a judicialização das relações sociais iluminam os dispositivos normativos - Constituição e CDC - por meio do princípio fundamental da dignidade da pessoa humana (CF, art. $1^{\circ}$, III), o qual promove uma repersonalização do direito privado, com ênfase em valores existenciais e do espírito, bem

acórdão Ministro Gilmar Mendes. Informativos (STF) n.(s) 351, 370, 385 e 405. Disponível em: $<$ http://www.stf.gov.br >. Acesso em: 20.10.2005).

${ }^{74}$ Ao ser perguntado pela platéia no IV Seminário de Direito Privado (organizado pelo IDP) sobre a ADI n. 2.591 como uma diretiva para a eficácia horizontal dos direitos fundamentais, o Ministro Gilmar Mendes sentiu-se ressabiado em afirmar que a ADI n. 2.591 seria um precedente norteador da eficácia horizontal dos direitos fundamentais nas relações entre particulares, mas prometeu uma reflexão sobre o tema (Cf. MENDES, Gilmar Ferreira. A Eficácia dos Direitos Fundamentais nas Relações Privadas. In: IV Seminário de direito privado - A constituição e a vida privada - Constituição e pessoa humana \& constituição e atividade econômica, 22 a 24 de junho de 2006. Brasília: Instituto Brasiliense de Direito Público, 2006).

${ }^{75}$ Cf. MARQUES, Cláudia Lima. Constituição, Direito Privado e o Consumidor. In: IV Seminário de direito privado - A constituição e a vida privada - Constituição e pessoa humana \& constituição e atividade econômica, 22 a 24 de junho de 2006. Brasília: Instituto Brasiliense de Direito Público, 2006.

${ }^{76}$ Cf. MARQUES, Cláudia Lima. Constituição, Direito Privado e o Consumidor. In: IV Seminário de direito privado - A constituição e a vida privada - Constituição e pessoa humana \& constituição e atividade econômica, 22 a 24 de junho de 2006. Brasília: Instituto Brasiliense de Direito Público, 2006.

${ }^{77}$ Cf. MARQUES, Cláudia Lima. Constituição, Direito Privado e o Consumidor. In: IV Seminário de direito privado - A constituição e a vida privada - Constituição e pessoa humana \& constituição e atividade econômica, 22 a 24 de junho de 2006. Brasília: Instituto Brasiliense de Direito Público, 2006. 
como no reconhecimento e no desenvolvimento dos direitos da personalidade, tanto em sua dimensão física quanto psíquica. ${ }^{78}$

Com efeito, a ADI n. 2591 garantiu o direito privado constitucionalmente, pois foi protagonista da abertura entre o diálogo das fontes (direito privado e Constituição), na medida em que se reconhece a Constituição como o centro do ordenamento jurídico ${ }^{79}$, conferindo uma lista de valores (CF, art. 170), falando-se de livre iniciativa (CF, art. $1^{\circ}$, IV) nas relações econômicas com a limitação da eficácia horizontal dos direitos fundamentais. ${ }^{80}$

Logo, as relações entre particulares operam direitos subjetivos, reconhecidos na lei ordinária (aplicação do CDC), cujo conteúdo deriva materialmente da Constituição ${ }^{81}$, existindo razoável consenso de que as normas constitucionais se aplicam, em alguma medida, às relações entre particulares. Nesse sentido, a aplicabilidade direta e imediata afigura-se mais adequada na realidade brasileira, e em sua ponderação, deve-se levar em conta os elementos do caso concreto, como (a) a desigualdade material entre as partes, (b) a manifesta injustiça e a falta de razoabilidade do critério, (c) a preferência para valores existenciais sobre os patrimoniais, e (d) o risco para a dignidade da pessoa humana. ${ }^{82}$

Nessa perspectiva, a constitucionalização, na linha do argumento aqui desenvolvido, expressa a irradiação dos valores constitucionais pelo sistema jurídico, dandose esta difusão da Lei Maior pelo ordenamento por meio da interpretação constitucional. ${ }^{83}$

Cumpre ressaltar que hoje, com a releitura da Constituição e a caracterização do Supremo Tribunal Federal com traços de Corte Constitucional, seria possível defender a tese que a limitação dos juros em $12 \%$ ao ano (CF, art. 192, § $3^{\circ}$ ) representaria um direito fundamental do cidadão, com a possibilidade de se opor esse mandamento constitucional de

${ }^{78}$ Cf. BARROSO, Luís Roberto. Neoconstitucionalismo e constitucionalização do Direito. O triunfo tardio do Direito Constitucional no Brasil. Jus Navigandi, Teresina, a. 9, n. 851, 01.11.2005. Disponível em: <http://jus2.uol.com.br/doutrina/texto.asp?id=7547>. Acesso em: 01.11.2005.

79 Trata-se do que Konrad Hesse denomina de "Força Normativa da Constituição”, fenômeno responsável por colocar a Constituição como guardiã e centro irradiador das novas linhas mestras do ordenamento jurídico, guiando tanto o direito público como o direito privado (cf. MARQUES, Cláudia Lima. Contratos no Código de Defesa do Consumidor. 3. ed., rev., atual. e ampl. São Paulo: Revista dos Tribunais, 1999, p. 226).

${ }^{80}$ Cf. MARQUES, Cláudia Lima. Constituição, Direito Privado e o Consumidor. In: IV Seminário de direito privado - A constituição e a vida privada - Constituição e pessoa humana, 22 a 24 de junho de 2006. Brasília: Instituto Brasiliense de Direito Público, 2006.

${ }^{81}$ Cf. HESSE, Konrad. Derecho Constitucional y derecho privado. Madrid: Civitas, 1995, p. 11.

${ }^{82}$ Cf. BARROSO, Luís Roberto. Neoconstitucionalismo e constitucionalização do Direito. O triunfo tardio do Direito Constitucional no Brasil. Jus Navigandi, Teresina, a. 9, n. 851, 01.11.2005. Disponível em: $<$ http://jus2.uol.com.br/doutrina/texto.asp?id=7547>. Acesso em: 01.11.2005.

${ }^{83}$ Cf. BARROSO, Luís Roberto. Neoconstitucionalismo e constitucionalização do Direito. O triunfo tardio do Direito Constitucional no Brasil. Jus Navigandi, Teresina, a. 9, n. 851, 01.11.2005. Disponível em: <http://jus2.uol.com.br/doutrina/texto.asp?id=7547>. Acesso em: 01.11.2005. 
maneira direta às instituições financeiras, haja vista que a EC n. 40, de 2003, não fora ainda impugnada pelos mecanismos de ações constitucionais, cabendo às entidades de classe de proteção ao consumidor e aos clientes bancários a propositura de ações constitucionais de controle para rediscutir o debate constitucional acerca da influência dos bancos na vida dos cidadãos. $^{84}$

Portanto, a revisão critica do Supremo Tribunal Federal e o estudo aprofundado da doutrina sobre a aplicação da boa-fé na lógica interna dos direitos fundamentais são necessários para concretizar uma coerência interna entre estes e a Constituição normativa, a qual repousa sobre o princípio da liberdade da pessoa humana, cujo conteúdo amplo e complexo constitui o núcleo essencial do princípio da autonomia da vontade nos âmbitos público e privado. ${ }^{85}$

Por fim, os valores estruturais do direito privado (igualdade, liberdade e fraternidade $^{86}$ - os quais constituem limite (ao outro cidadão) ou poder (garantia) - se encontram em consonância com o sistema de valores constitucionais, responsáveis pelo preenchimento das diretrizes internas do Direito Civil ${ }^{87}$, porque toda vez que estiver em cena um direito fundamental haverá a primazia sobre o direito privado, em razão da força normativa e da prevalência dos direitos humanos (CF, art. $5^{\circ}, \S 2^{\circ}$ ). Deve-se, assim, pensar o

\footnotetext{
${ }^{84}$ Sobre esse aspecto, O Ministro Gilmar Mendes acredita que o art. 192, § $3^{\circ}$, da Constituição é um dispositivo que enseja conflitos hermenêuticos no âmbito do STF. Nesse aspecto, a sua caracterização como direito subjetivo público - para ser colocado no plano da eficácia horizontal dos direitos fundamentais nas relações entre particulares - deve observar um contexto institucional, em especial o quadro do sistema financeiro, a fim de oportunizar a ponderação de valores (cf. MENDES, Gilmar Ferreira. A Eficácia dos Direitos Fundamentais nas Relações Privadas. In: IV Seminário de direito privado - A constituição e a vida privada Constituição e pessoa humana \& constituição e atividade econômica, 22 a 24 de junho de 2006. Brasília: Instituto Brasiliense de Direito Público, 2006. Acerca da perspectiva institucional dos direitos fundamentais, cf. HÄBERLE, Peter. La libertad fundamental en el Estado Constitucional. Trad. Jürgen Saligmann, César Landa, Carlos Ramos e Antonio Luya. San Miguel, Peru: Fondo Editorial de la Pontificia Universidad Católica del Peru, 1997).

${ }^{85}$ Cf. RODRIGUEZ RUIZ, Bianca. Resenha do livro de NARANJO DE LA CRUZ, Rafael. Los límites de los derechos y fundamentales en las relaciones entre particulares: la buena fe. Madrid: Centros de Estudios Políticos y Constitucionales, 2000. In: Teoría y realidad constitucional, n. 10-11, p. 792-798, 2003, p. 797798. Disponível em: <http://www.juridicas.unam.mx/publica/librev/rev/trcons/cont/10/rec/rec35.pdf>. Acesso em: 25.10.2005.

86 Sobre o fundamento e conteúdo essencial desses valores, cf. HÄBERLE, Peter. Libertad, Igualdad, Fraternidad: 1789 como historia, actualidad y futuro del Estado Constitucional. Trad. Ignacio Gutiérrez Gutiérrez. Madri: Minima Trotta, 1998.

${ }^{87}$ A esse respeito, destaca-se a cláusula da função social dos contratos (CC, art. 421), a boa-fé objetiva (CC, art.

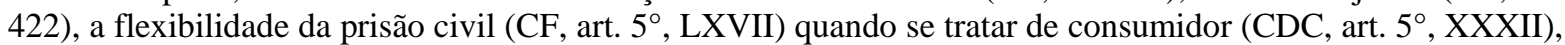
além da nulidade das cláusulas inconstitucionais, quando se tratar da cláusula geral do "abuso de direito" (CC, art. 187, c/c CDC, art. $7^{\circ}$ ), ao exceder os fins econômicos e sociais, contrariando a boa-fé e os bons costumes (cf. MARQUES, Cláudia Lima. Constituição, Direito Privado e o Consumidor. In: IV Seminário de direito privado - A constituição e a vida privada - Constituição e pessoa humana \& constituição e atividade econômica, 22 a 24 de junho de 2006. Brasília: Instituto Brasiliense de Direito Público, 2006).
} 
direito privado em uma visão humanística, confiando ao espaço institucional do STF a possibilidade do diálogo das fontes, em busca de (re)unir o direito privado ao público. ${ }^{88}$

\section{Conclusão}

Reconhecendo a vulnerabilidade do consumidor (CDC, art. $4^{\circ}$, I) no que diz respeito ao conteúdo dos contratos bancários, o Supremo Tribunal Federal considerou viável a aplicação do Código de Defesa do Consumidor nas relações bancárias.

Verifica-se que a afirmação do Ministro Nelson Jobim de que as atividades bancárias pertencem à política monetária e por essa razão devem ser compartilhadas por todos não se justifica, pois o cidadão não pode pagar pelos erros e desacertos dos outros. Para que se estabeleça uma relação institucional entre cliente bancário e banco, estes devem observar o dever geral de informação, pois o cliente não é um especialista em contratos bancários.

Nesse sentido, a teoria da eficácia imediata dos direitos fundamentais nas relações privadas - tanto na perspectiva da teoria sistêmica pós-moderna, como na teoria do discurso encontra seu espaço no âmbito de aplicação no direito privado, uma vez que a dignidade da pessoa humana e a boa-fé podem ser consideradas como alicerces dessa teoria na concretização dos direitos fundamentais dos cidadãos.

Nos dias atuais, a dignidade da pessoa humana está atrelada à atividade bancária. Não se realiza uma compra de produtos de extrema necessidade sem pelo menos um serviço da cadeia bancária. É necessário, pois, salientar o dever de informação por parte das instituições financeiras e o dever de fiscalização por parte dos setores da sociedade civil organizada e do Poder Público, a fim de restabelecer a clareza das relações entre os clientes consumidores e as instituições financeiras, fornecedoras de serviços essenciais à sobrevivência do cidadão no cotidiano moderno.

Ademais, o julgamento da ADI n. 2.591 abriu perspectivas para a caracterização do diálogo das fontes no âmbito institucional do Supremo Tribunal Federal, tendo em vista a aproximação do direito público com o privado em razão da Constitucionalização do Direito, o que torna a ADI n. 2.591 um precedente que concretiza os direitos fundamentais nas relações privadas.

\footnotetext{
${ }^{88}$ Cf. MARQUES, Cláudia Lima. Constituição, Direito Privado e o Consumidor. In: IV Seminário de direito privado - A constituição e a vida privada - Constituição e pessoa humana \& constituição e atividade econômica, 22 a 24 de junho de 2006. Brasília: Instituto Brasiliense de Direito Público, 2006.
} 
Assim, insiste-se no ponto de que hoje, com a releitura da Constituição e a caracterização do Supremo Tribunal Federal com fortes traços de uma Corte Constitucional, seria possível defender a tese que a limitação dos juros em 12\% ao ano (CF, art. 192, § $3^{\circ}$ ) representaria um direito fundamental do cidadão, com a possibilidade de se opor esse mandamento constitucional de maneira direta às instituições financeiras, haja vista que a EC n. 40, de 2003, ainda não fora impugnada pelos mecanismos de ações constitucionais, cabendo às entidades de classe de proteção ao consumidor e aos clientes bancários a propositura de ações constitucionais de controle para rediscutir o debate constitucional acerca da influência dos bancos na vida dos cidadãos.

Artigo recebido em julho de 2006

Aceito para publicação em abril de 2007

\section{Referências}

ALEJANDRO AMAYA, Jorge. El habeas data: una garantía en dos dimensiones. In:

BAZÁN, Víctor (coord.). Defensa de la Constitución: garantismo y controles. Buenos Aires: Editar, 2003.

ÁVILA, Humberto Bergmann. Teoria dos princípios: da definição à aplicação dos princípios jurídicos. 3. ed., aumentada. São Paulo: Malheiros Editores, 2004.

BARROSO, Luís Roberto. Neoconstitucionalismo e constitucionalização do Direito. O triunfo tardio do Direito Constitucional no Brasil. Jus Navigandi, Teresina, a. 9, n. 851, 01.11.2005. Disponível em: <http://jus2.uol.com.br/doutrina/texto.asp?id=7547> . Acesso em: 01.11.2005.

DIRETO DO PLENÁRIO: Regras do Código de Defesa do Consumidor valem para os bancos. Últimas Notícias (STF), 07.06.2006. Disponível em: <http://www.stf.gov.br>. Acesso em: 07.06.2006.

FÉRES, Marcelo Andrade. Aplicação do Código de Defesa do Consumidor às instituições financeiras: exame de constitucionalidade. Jus Navigandi, Teresina, a. 10, n. 937, 26.01.2006. Disponível em: <http://jus2.uol.com.br/doutrina/texto.asp?id=7876>. Acesso em: 24.05.2006.

GONÇALVES, Rogério Magnus Varela. Os direitos fundamentais e sua validade no âmbito das relações privadas. Prim@ Facie: Revista da Pós-Graduação Ciências Jurídicas Universidade Federal da Paraíba, a. 03, n. 5, p. 73-100, jul./dez. 2004. Disponível em: <http://www.ccj.ufpb.br/primafacie/prima/artigos/n5/direitos.pdf > . Acesso em: 29.06.2006. 
HÄBERLE, Peter. Hermenêutica Constitucional. A sociedade aberta de intérpretes da Constituição: contribuição para a interpretação pluralista e "procedimental” da Constituição. Trad. Gilmar Ferreira Mendes. Porto Alegre: Sergio Antonio Fabris, 1997.

HÄBERLE, Peter. La libertad fundamental en el Estado Constitucional. Trad. Jürgen Saligmann, César Landa, Carlos Ramos e Antonio Luya. San Miguel, Peru: Fondo Editorial de la Pontificia Universidad Católica del Peru, 1997.

HÄBERLE, Peter. Libertad, Igualdad, Fraternidad: 1789 como historia, actualidad y futuro del Estado Constitucional. Trad. Ignacio Gutiérrez Gutiérrez. Madri: Minima Trotta, 1998.

HESSE, Konrad. Derecho Constitucional y derecho privado. Madrid: Civitas, 1995.

KHOURI, Paulo Roberto Roque Antonio. Direito do Consumidor: contratos, responsabilidade civil e defesa do consumidor em juízo. 2. ed., São Paulo: Atlas, 2005.

LINETZKY, Andrés Jana. La eficacia horizontal de los derechos fundamentales. Yale Law School: Seminario en Latino América de Teoría Constitucional y Política. Disponível em: $<$ http://islandia.law.yale.edu/sela/sjana.pdf>. Acesso em: 28.07.2006.

MARQUES, Cláudia Lima. Constituição, Direito Privado e o Consumidor. In: IV Seminário de direito privado - A constituição e a vida privada - Constituição e pessoa humana \& constituição e atividade econômica, 22 a 24 de junho de 2006. Brasília: Instituto Brasiliense de Direito Público, 2006.

MARQUES, Cláudia Lima. Contratos no Código de Defesa do Consumidor. 3. ed., rev., atual. e ampl. São Paulo: Revista dos Tribunais, 1999.

MARQUES, Cláudia Lima; BENJAMIN, Antônio Herman V; MIRAGEM, Bruno.

Comentários ao Código de Defesa do Consumidor: arts. $1^{\circ}$ a 74 aspectos materiais. São Paulo: Revista dos Tribunais, 2003.

MARTINS, Leonardo (org.). Cinqüenta Anos de Jurisprudência do Tribunal

Constitucional Federal Alemão. Coletânea original: Jürgen Schwabe. Montevideo, Uruguay: Fundación Konrad-Adenauer, 2005.

MENDES, Gilmar Ferreira. A Eficácia dos Direitos Fundamentais nas Relações Privadas. In: IV Seminário de direito privado - A constituição e a vida privada - Constituição e pessoa humana \& constituição e atividade econômica, 22 a 24 de junho de 2006. Brasília: Instituto Brasiliense de Direito Público, 2006.

NARANJO DE LA CRUZ, Rafael. Los límites de los derechos y fundamentales en las relaciones entre particulares: la buena fe. Madrid: CEPC, 2002.

OLIVEIRA, Celso Marcelo de. O STF, o direito do consumidor e os contratos bancários. Jus Navigandi, Teresina, a. 6, n. 57, jul. 2002. Disponível em:

<http://jus2.uol.com.br/doutrina/texto.asp?id=3018>. Acesso em: 24.05.2006.

RODRIGUEZ RUIZ, Bianca. Resenha do livro de NARANJO DE LA CRUZ, Rafael. Los límites de los derechos y fundamentales en las relaciones entre particulares: la buena fe. 
Madrid: Centros de Estudios Políticos y Constitucionales, 2000. In: Teoría y realidad constitucional, n. 10-11, p. 792-798, 2003. Disponível em:

<http://www.juridicas.unam.mx/publica/librev/rev/trcons/cont/10/rec/rec35.pdf>. Acesso em: 25.10.2005.

SARLET, Ingo Wolfgang. Direitos Fundamentais e Direito Privado: algumas considerações em torno da vinculação dos particulares aos direitos fundamentais. In: Revista de Direito do Consumidor, São Paulo: Revista dos Tribunais, n. 36, p. 54-103, out./dez. 2000.

SILVA, Christine Oliveira Peter da. A pesquisa científica na graduação em Direito. In: Universitas/ Jus: Brasília, n. 11, p. 25-43, dez. 2004.

SILVA, Christine Oliveira Peter da. Discussões prático-metodológicas sobre relatórios de pesquisa no contexto da iniciação científica em Direito. In: Universitas/ Jus: Revista da Faculdade de Ciências Jurídicas e Ciências Sociais do Centro Universitário de Brasília UniCEUB. Brasília, n. 12, p. 39-54, jul. 2005.

SILVA, Christine Oliveira Peter da. Hermenêutica Constitucional e os Princípios Norteadores da Concretização das Normas Constitucionais. Notícias do Direito Brasileiro. Brasília: UnB, n. 09, p. 155-175, 2002.

SILVA, Christine Oliveira Peter da. Hermenêutica de Direitos Fundamentais: uma proposta constitucionalmente adequada. Brasília: Brasília Jurídica, 2005.

SILVA, Christine Oliveira Peter da. Interpretação constitucional no século XXI: o caminhar metodológico para o concretismo constitucional sob a influência de Peter Häberle. Direito Público. Porto Alegre: Síntese; Brasília: Instituto Brasiliense de Direito Público, a. 02., n. 08, p. 05-39, abr./jun. 2005.

SILVA, Christine Oliveira Peter da. Metodologia de pesquisa científica e o Direito Constitucional. In: Universitas/ Jus: Revista da Faculdade de Ciências Jurídicas e Ciências Sociais. Brasília, n. 09, p. 247-262, jul./dez. 2002.

SUPREMO TRIBUNAL FEDERAL. 1. Turma. RE n. 286.963-MG. Relator Ministro Sepúlveda Pertence. Informativo (STF) n. 386. Disponível em: <http://www.stf.gov.br>. Acesso em 04.06.2006.

SUPREMO TRIBUNAL FEDERAL. 2. Turma. RE n. 201.819. Relatora. Ministra Ellen Gracie. Relator para o acórdão Ministro Gilmar Mendes. Informativos (STF) n.(s) 351, 370, 385 e 405. Disponível em: <http://www.stf.gov.br>. Acesso em: 20.10.2005.

SUPREMO TRIBUNAL FEDERAL. Plenário. ADI n. 2.951-DF. Relator Ministro Carlos Velloso. Voto do Ministro Eros Grau. Últimas Notícias (STF). Disponível em: $<$ http://www.stf.gov.br>. Acesso em 01.06.2006.

SUPREMO TRIBUNAL FEDERAL. Plenário. ADI n. 2.951-DF. Relator Ministro Carlos Velloso. Voto do Ministro Néri da Silveira. Informativo (STF) n. 264. Disponível em: $<$ http://www.stf.gov.br>. Acesso em 01.06.2006. 
SUPREMO TRIBUNAL FEDERAL. Plenário. ADI n. 2.951-DF. Relator Ministro Carlos Velloso. Voto do Ministro Nelson Jobim. Últimas Notícias (STF). Disponível em:

$<$ http://www.stf.gov.br>. Acesso em 01.06.2006.

SUPREMO TRIBUNAL FEDERAL. Plenário. ADI n. 319-QO. Relator Ministro Moreira Alves, DJ 30.04.1993. Disponível em: <http://www.stf.gov.br>. Acesso em 01.06.2006.

SUPREMO TRIBUNAL FEDERAL. Plenário. MI n. 542. Relator Ministro Celso de Mello, DJ 28.06.2002. Disponível em: <http://www.stf.gov.br>. Acesso em 01.06.2006.

SUPREMO TRIBUNAL FEDERAL. RE n. 387.404. Relator para acórdão Ministro Joaquim Barbosa, DJ 26.03.2004. Disponível em: <http://www.stf.gov.br>. Acesso em 04.06.2006.

VIEIRA, Liliane dos Santos. Pesquisa e monografia jurídica na era da informática. 2. ed. Brasília, Brasília Jurídica, 2005. 


\section{Resumo}

Este artigo tem por objetivo iluminar as relações de consumo nos contratos bancários com a teoria da eficácia imediata dos direitos fundamentais nas relações entre particulares. Teoria, essa, que, segundo o argumento desenvolvido, é aplicável no âmbito do direito privado, uma vez que a dignidade da pessoa humana e a boa-fé podem ser consideradas como alicerces dessa teoria na concretização dos direitos fundamentais. $\mathrm{O}$ julgamento da ADI n. 2.591 abriu perspectivas para a caracterização do diálogo das fontes no âmbito institucional do STF, tendo em vista a aproximação do direito público com o privado (Constitucionalização do Direito), o que torna a ADI n. 2.591 um precedente concretizador dos direitos fundamentais nas relações privadas.

Palavras-chave: Relação de Consumo. Bancos. Supremo Tribunal Federal. Direitos Fundamentais nas Relações Privadas.

\begin{abstract}
This articles attempts to illuminate certain aspects of consumer relations regarding bank contracts and the theory of immediate efficiency of fundamental rights in private relations. This theory, following the thought line that is presented here, can and should be applied in the private sphere of rights, because human dignity and good faith can be considered as pillars for the concretization of fundamental rights. The judgment of a constitutional proceeding (ADI n. 2.591) opened new channels of dialogue within the institutional environment of the Brazilian Supreme Court. In this manner, this suit is becoming a strong precedent in the concretization of fundamental rights within private relations.
\end{abstract}

Keywords: Consumer Relations. Banks. Brazilian Supreme Court. Human Rights within Private Relations. 